\title{
Interpretation of Recent Unrest Events (Bradyseism) at Campi Flegrei, Napoli (Italy): Comparison of Models Based on Cyclical Hydrothermal Events versus Shallow Magmatic Intrusive Events
}

\author{
A. Lima $\mathbb{D}^{1},{ }^{1}$ R. J. Bodnar, ${ }^{2}$ B. De Vivo, ${ }^{3}$ F. J. Spera, ${ }^{4}$ and H. E. Belkin ${ }^{5}$ \\ ${ }^{1}$ Dipartimento di Scienze della Terra, dell'Ambiente e delle Risorse (DiSTAR), Università di Napoli Federico II, \\ Complesso Universitario di Monte Sant'Angelo, Via Cintia 26, 80126 Napoli, Italy \\ ${ }^{2}$ Department of Geosciences, Virginia Tech, Blacksburg, Virginia 24061, USA \\ ${ }^{3}$ Pegaso Online University, Piazza Trieste e Trento, 48, 80132 Napoli, Italy \\ ${ }^{4}$ Department of Earth Sciences, University of California, Santa Barbara, CA, USA 93106 \\ ${ }^{5}$ U. S. Geological Survey Retired, Reston, Virginia 20190, USA
}

Correspondence should be addressed to A. Lima; anlima@unina.it

Received 8 June 2021; Accepted 7 September 2021; Published 14 October 2021

Academic Editor: Andri Stefansson

Copyright (c) 2021 A. Lima et al. This is an open access article distributed under the Creative Commons Attribution License, which permits unrestricted use, distribution, and reproduction in any medium, provided the original work is properly cited.

\begin{abstract}
Several recent models that have been put forth to explain bradyseism at Campi Flegrei (CF), Italy, are discussed. Data obtained during long-term monitoring of the CF volcanic district has led to the development of a model based on lithological-structural and stratigraphic features that produce anisotropic and heterogeneous permeability features showing large variations both horizontally and vertically; these data are inconsistent with a model in which bradyseism is driven exclusively by shallow magmatic intrusions. CF bradyseism events are driven by cyclical magmatic-hydrothermal activity. Bradyseism events are characterized by cyclical, constant invariant signals repeating over time, such as area deformation along with a spatially welldefined seismogenic volume. These similarities have been defined as "bradyseism signatures" that allow us to relate the bradyseism with impending eruption precursors. Bradyseism is governed by an impermeable shallow layer (B-layer), which is the cap of an anticlinal geological structure culminating at Pozzuoli, where maximum uplift is recorded. This B-layer acts as a throttling valve between the upper aquifer and the deeper hydrothermal system that experiences short $\left(1-10^{2} \mathrm{yr}\right)$ timescale fluctuations between lithostatic/hydrostatic pressure. The hydrothermal system also communicates episodically with a cooling and quasi-steady-state long timescale $\left(10^{3}-10^{4} \mathrm{yr}\right)$ magmatic system enclosed by an impermeable carapace (A layer). Connectivity between hydrostatic and lithostatic reservoirs is episodically turned on and off causing alternatively subsidence (when the systems are connected) or uplift (when the systems are disconnected), depending on whether permeability by fractures is established or not. Earthquake swarms are the manifestation of hydrofracturing which allows fluid expansion; this same process promotes silica precipitation that seals cracks and serves to isolate the two reservoirs. Faults and fractures promote outgassing and reduce the vertical uplift rate depending on fluid pressure gradients and spatial and temporal variations in the permeability field. The miniuplift episodes also show "bradyseism signatures" and are well explained in the context of the short timescale process.
\end{abstract}

\section{Introduction}

About a billion people, roughly $15 \%$ of the world population, live in areas of volcanic risk because many population centers developed around dormant volcanoes that have not erupted in recent years. The Neapolitan volcanic area is one such high volcanic risk area [1], with about three million people living within an area with a radius of $\sim 25 \mathrm{~km}$ in a volcanic province that includes active volcanoes such as Vesuvius, Campi Flegrei (CF), and Ischia [2] (Figure 1(a)).

The CF is currently the area at greatest risk within the Neapolitan volcanic area as it is actively experiencing the 


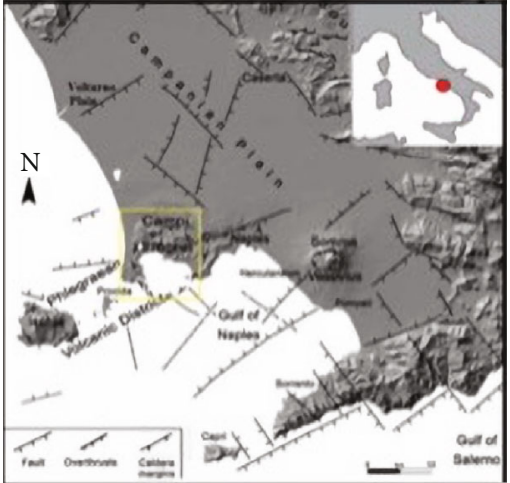

(a)

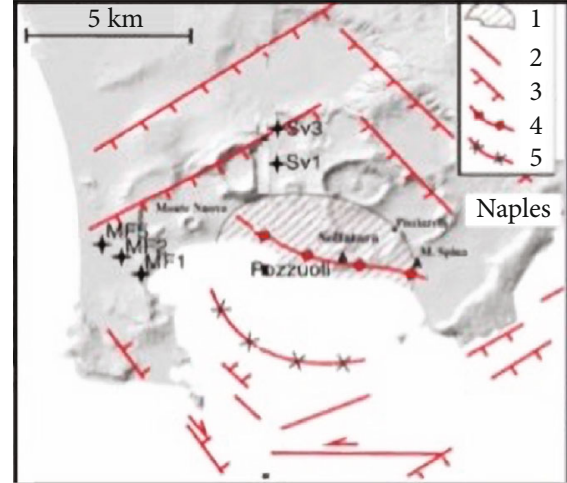

(b)

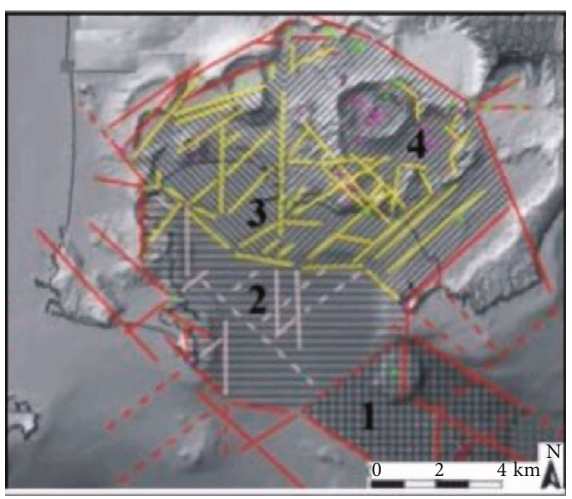

(c)

Figure 1: (a) Structural sketch map of the Campanian Plain and surrounding Apennines. (b) Structural map of the CF-Pozzuoli Bay area: (1) area affected by an uplift of 100-50\% during the 1982-84 bradyseism; (2) fractures and lateral faults; (3) normal faults; (4) Pozzuoli anticline; (5) Pozzuoli Bay syncline. Black stars geothermal wells: MF = Mofete; SV = San Vito (from Milia et al. [17]; Milia and Torrente [18]). (c) Structural sketch map of CF caldera: (1) sector deformed during caldera collapse; (2) undeformed to subsiding portion of the caldera floor; (3) eastern sector of the resurgent portion of the caldera floor; (4) western sector of the resurgent portion of the caldera floor; red lines = regional faults activated during caldera collapse; yellow lines = regional faults reactivated during resurgence of a portion of the caldera floor; white lines = regional faults reactivated during subsidence of a portion of the caldera floor (modified from Capuano et al. [96]).

phenomenon of ground uplift and subsidence called bradyseism (from the Greek, meaning "slow movement"), a term introduced by ancient Greeks who populated the area before the Romans [3]. For this reason, the region is continuously monitored using a variety of geophysical (seismicity), geochemical (composition of emitted gasses and fluids), and volcanological tools in order to better constrain and understand the volcanic hazard. The geology (sensu lato) of CF has been intensively studied for the last century by applying modern ideas and methods, and yet, significant differences of opinion exist regarding the fundamental processes leading to bradyseism over the past few thousand years. The need to better understand $\mathrm{CF}$ volcanic activity is fundamental to protect the population from hazards linked to explosive volcanic eruptions and to understand the role of seismicity as a possible precursor of a potential future eruption. CF experienced many bradyseism episodes since at least GreekRoman time, but only once, in $1538 \mathrm{CE}$, after a ground uplift of $\sim 7 \mathrm{~m}$, was there a recorded eruption (Monte Nuovo) [4]. After the $1538 \mathrm{CE}$ eruption, a long period of subsidence ensued until 1950 when a phase of rapid uplift of about $0.8 \mathrm{~m}$ started, followed by about twenty years of subsidence that lasted until 1969 [3]. There were two other dramatic bradyseism phases in 1969-1972 and 1982-1984, always starting with uplift followed by an amount of subsidence that did not balance the preceding uplift [3], i.e., the subsidence phase did not return the surface to its initial preuplift level (Figure 2).

Unrest in 1982-84 was especially concerning; it resulted in $\sim 1.8 \mathrm{~m}$ of uplift and $\sim 16,000$ associated earthquakes, most of which were of low magnitude $[5,6]$. After a $\sim 22$-year period of subsidence, a new phase of slow uplift began at the end of 2005 and continues to the present time. From 1984 to today, several sharp and short bradyseism episodes (displacements generally $\sim 0.1 \mathrm{~m}$ or less) have been registered: in 1989, 1994, 2000, 2006, and 2012-2013 (Figure 2). Since 1950, all bradyseism episodes have followed very similar ground deformation patterns, with only uplift and subsidence rates and magnitudes showing variation [7]. Inflation events are accompanied by seismic crises that define a spatially fixed seismogenic volume during unrest with a circular shape (radius $\sim 6 \mathrm{~km}$ ) around the town of Pozzuoli, where the greatest uplift is observed. The magnitude of the uplift and seismicity both decrease in intensity toward the margins of the circular uplift region [5-11]. 


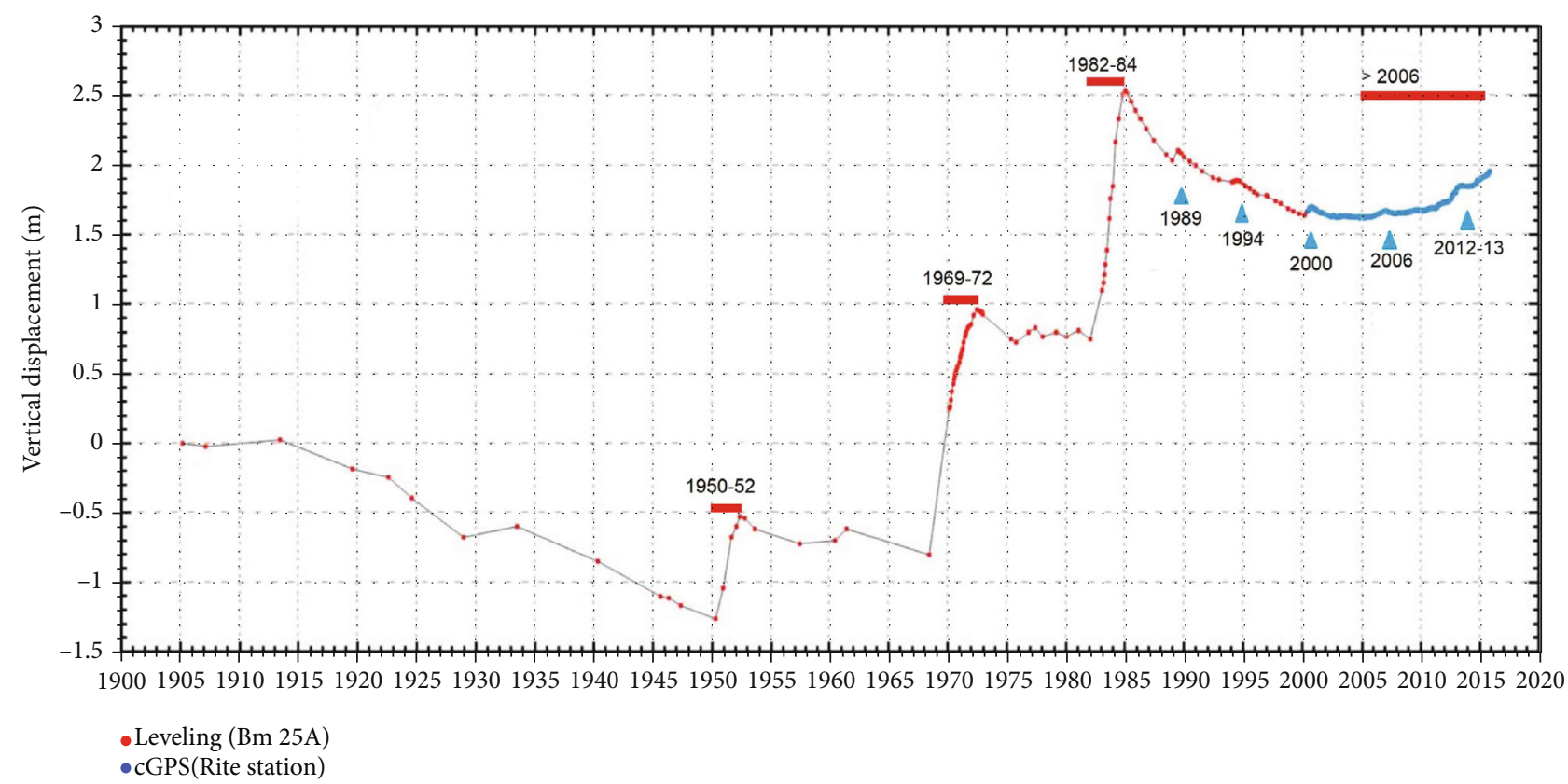

Figure 2: Ground displacement at Pozzuoli Porto since 1905, measured by precision leveling (until year 2000, in red) and at the close GPS benchmark of Rione Terra (since 2000, blue dots) (from Moretti et al. [60]).

In this review, we relate the recent $\mathrm{CF}$ bradyseism events to cyclical magmatic-hydrothermal processes that are characteristic of the cooling and crystallization of epizonal, water-bearing magmas, as first described by De Vivo and Lima [12]. A quantitative conceptual model describing this process was later reported by Bodnar et al. [13], followed by a rigorous thermodynamic model describing the process [14]. Here, we first emphasize that bradyseism displays repetitive cyclical signals without substantial variations in terms of recognizable signatures; the latter can be helpful to distinguish bradyseism from impending eruption precursors. Secondly, by combining the cyclical model with results of other investigations, we show that the bradyseism mechanism is not linked to recent shallow emplacement of magmatic intrusions as proposed in the recent literature. Finally, we show that the cyclical nature of the observed bradyseism is closely related to the complex geological, tectonic, and stratigraphic upper crustal structures that govern spatial and temporal variations of the subsurface permeability.

\section{Geological-Structural Pattern, Volcanic History, and Models for Recent Bradyseism at Campi Flegrei}

2.1. Geological-Structural Pattern. The CF volcanic complex is located within the upper Pliocene graben structure of the Campanian Plain that developed on the western margin of the Apennine Mountain chain after the opening of the Tyrrhenian Basin (Figure 1(a)). The NW-SE extensional tectonics, connected to the opening phases of the Tyrrhenian Sea, controlled the morphosedimentary evolution of the Campania coast while volcanism was still active. In the period from $700 \mathrm{ka}$ to $400 \mathrm{ka}$, several deep sedimentary basins formed, including the Volturno Plain, Gulf of Pozzuoli, Gulf of Naples, and Salerno (Figure 1(a)). The boundaries of the $\mathrm{CF}$ area onshore and offshore are characterized by highangle faults. In the CF caldera area, a compressional tectonic regime is active, with an anticline culminating near the town of Pozzuoli and a syncline located beneath Pozzuoli Bay (Figure 1(b)). The rate of fold uplift ranges from 1 to $20 \mathrm{~mm} / \mathrm{yr}$ [15-19]. Other studies (e.g., [20]) generally report an extensional tectonic regime without going into much detail in the area within the caldera. The structural sketch map of the CF caldera (Figure 1(c)) shows the limit between eastern and western resurgent caldera sectors passing through the town of Pozzuoli, where the anticline culminates and where during bradyseism events, the maximum elevation changes are recorded.

In the Campania Plain, volcanism started with fissuresourced ignimbrite events (from $>300$ to $19 \mathrm{ka}$ ) [21-23] and is still active in the Neapolitan area (Mt. Vesuvius and $\mathrm{CF}$ ). In spite of the evidence reported by de Vivo et al. [21] and Rolandi et al. [22], before 2012, most authors reported that the CF caldera was formed by two eruptions, the Campania Ignimbrite (CI) at $39 \mathrm{ka}$ and later by the Neapolitan Yellow Tuff eruption (NYT) at $15.6 \mathrm{ka}([24,25]$ and ref. therein). In 2012, a $506 \mathrm{~m}$ drill-hole in the Bagnoli plain in the CF eastern sector revealed that the CI volume is much lower than the NYT volume, in contrast to the hypothesis that the CI source was in the CF area, and supporting the hypothesis that the collapse at CF only occurred during the NYT eruption $[26,27]$. The latter finding also implies that most of Naples urban area does not lie within the CF caldera. At least 73 phreatomagmatic eruptions younger than NYT are known to occur within the caldera area, grouped into three periods: epoch I 15.6-9.5 ka, epoch II 8.6-8.2 ka, and epoch III $4.5-3.8 \mathrm{ka}([28,29]$ and ref. therein, [30]). In the 
last $3.8 \mathrm{ka}$, only one eruption (Monte Nuovo; $1538 \mathrm{CE}$ ) occurred [4]. The spatial and temporal migration of volcanic activity after the eruption of the NYT toward the center of the caldera combined with a major reduction in the volumes and an evolution in the chemistry of the erupted products suggests that recent CF activity represents the evolution of a large cooling magma chamber [31].

2.2. History of Bradyseism. Since Roman times, the Pozzuoli area has undergone several uplift episodes followed always by subsidence. In 1905, the Istituto Geografico Militare (IGM) initiated precise leveling of CF establishing a line along the coast of Pozzuoli Gulf; before 1905, no precise leveling measurements are available [32]. After about $3.8 \mathrm{ka}$, when the last, large, explosive Monte Spina eruption occurred, a very small eruption of $0.02 \mathrm{~km}^{3}$ occurred in 1538 CE, forming Monte Nuovo (New Mountain) [4]. The 1538 eruption was preceded by about one hundred years of ground uplift marked by sea recession, and the area of greatest uplift was centered on the site of the eruption $(3 \mathrm{~km}$ west of Pozzuoli) [3]. After the 1538 eruption, slow, regular subsidence occurred. The latter has been well documented after 1819 with the first measurements of sea level above the Serapis Temple floor, an archaeological site in Pozzuoli. More recently, bradyseismic events occurred in 1950-1952, 19691972, and 1982-1984 (Figure 2). The latter was of great concern for the inhabitants of Pozzuoli due to the magnitude of the uplift of about $180 \mathrm{~cm}$, followed by $80 \mathrm{~cm}$ subsidence in the following 20 years [32]. At the end of 2005, slow uplift started again at rates comparable to those of subsidence (on average $\sim 4 \mathrm{~cm} / \mathrm{yr}$ ) and the uplift continues today at an accelerating rate (Figure 2). During post-1984 subsidence and during the subsequent and still ongoing uplift, minor abrupt episodes of uplift, followed by minor subsidence and fast recovery of the whole uplift, have been registered in 1989, 1994, 2000, 2006, 2012-2013, and 2016 (Figure 2) [33]. The 2012-2013 uplift rate was faster $(\sim 16 \mathrm{~cm} / \mathrm{yr})$ than the others and has been studied in more detail [34]. In early 1982 , uplift was quick $(\sim 100 \mathrm{~cm} / \mathrm{yr})$ and earthquakes reached significant magnitude in 1983. During 1984, the uplift continued, and the seismicity was very intense, with 33 events with $M \geq 3.0$ and six events with $M \geq 3.8$ (Figure 3) [6]. At the end of 1984, after an uplift of $1.79 \mathrm{~m}$ (Figure 2), subsidence started and seismicity quickly decreased and the composition of fumaroles at Solfatara, a volcano near Pozzuoli, recorded a greater contribution of magmatic gas [35].

2.3. Bradyseism Associated with Shallow Magma Intrusions. Since 2010 almost all published studies interpreted CF unrest to be the result of intrusion of magmas to shallow depths of $\sim 3 \mathrm{~km}$ (e.g., [5, 33, 36-49]). For a more extensive review on bradyseism interpretations, see Cannatelli et al. ([50] and ref. therein).

In the 2000s, De Vivo and Lima [12], Battaglia et al. [51], and Bodnar et al. [13] were the first to speculate that migration of fluid within the caldera hydrothermal system was the cause of ground deformation and consequent unrest, rather than intrusion of magma. Battaglia et al. [51] came to this conclusion by inverting leveling, trilateration, and gravity measurements collected between 1980 and 1995; they modeled the location, geometry, and density of the deformation source. Densities obtained were compatible with fluid density. Other studies [36, 38, 41, 43, 44, 52] also utilizing deformation and microgravity data found different densities mostly attributed to differentiated magma. Woo and Kilburn [41] reported that a sill-shaped magma intrusion, coming from the deeper reservoir and emplaced at a depth of $\sim 3 \mathrm{~km}$, gave rise to the recorded ground deformation for 1982-1984 unrest, similar to previous studies [36, 38]. Subsequent subsidence was attributed, by the latter authors, to temporary pressure changes in the aquifer caused by magmatic intrusion, but without details. Woo and Kilburn [41] corroborate the interpretation of Bellucci et al. [53] that all CF bradyseismic events are caused by sill intrusions, centered in the vicinity of Pozzuoli, the location of maximum uplift. Since 2010, most published papers agree with the Woo and Kilburn [41] model and have focused on developing more convincing explanations for the subsidence that always follows uplift $[33,54-61]$. Noteworthy is the Macedonio et al. [55] model that associates uplift with sill magmatic injection that at the center of intrusion stops and rapidly spreads laterally; the injected magma accommodates by a further lateral expansion of the sill, so that the maximum uplift slightly decreases causing subsidence. For the 198284 event, the interpretation of Troise et al. [33] agrees with the Woo and Kilburn [41] model but argues that the sillshaped magma intrusion caused an uplift of $\sim 110 \mathrm{~cm}$ and the subsequent uplift of $\sim 70 \mathrm{~cm}$ (to achieve the total uplift of $\sim 180 \mathrm{~cm}$ ) was due to the influx of deep fluids which over the next 20 years led to a slow subsidence. The miniuplifts, as defined by Gaeta et al. [62], registered during both subsidence and uplift (Figure 2), have been interpreted by most in the same way $[44,57-59,63-65]$. The 2012-2013 unrest was also interpreted to be the result of a shallow magma intrusion, and this triggered the Italian Civil Protection to increase the volcanic alert level in CF area ("Yellow" level) in December 2012. Troise et al. [33] did not support this interpretation and hypothesized that the miniuplifts can be caused by a periodic increase of deep fluid injection or periodic self-sealing of the porous medium in which deep fluids are injected, without explaining the details.

Chiodini et al. [66] measured the fumarolic gas composition and $\mathrm{CO}_{2}$ fluxes in the Solfatara and Pisciarelli areas during the last 10 years and argued that magmatic fluids related to magma intrusion at depth cause volcanic unrest because they heat and pressurize the CF hydrothermal system which in turn transfers energy to the host rocks triggering low magnitude seismicity and gas emissions. The geobarometric and geothermometric relations have been determined by mass balance considering that $\mathrm{H}_{2} \mathrm{O}$ and $\mathrm{CO}_{2}$ react to form $\mathrm{H}_{2}, \mathrm{CO}$, and $\mathrm{CH}_{4}$. They calculated that the pressure-temperature increase at the top of a vertically elongated $(0.3-2 \mathrm{~km}$ deep) gas front is responsible for low magnitude earthquakes and surface $\mathrm{CO}_{2}$ gas emissions registered in the last years.

The involvement of shallow magma intrusions is based on the decreasing $\mathrm{H}_{2} \mathrm{O} / \mathrm{CO}_{2}$ ratio in gas composition of the Solfatara volcano fumaroles since 2000 [57-61] (Figure 4(a)). 


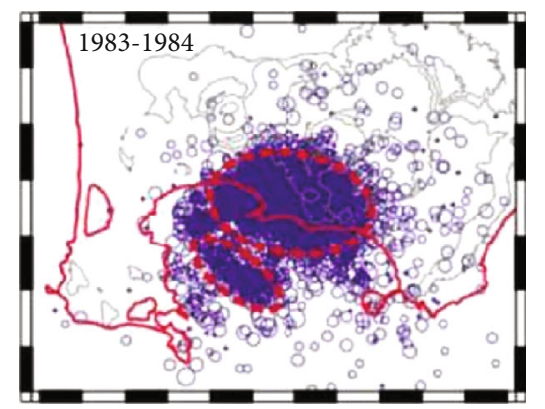

(a)

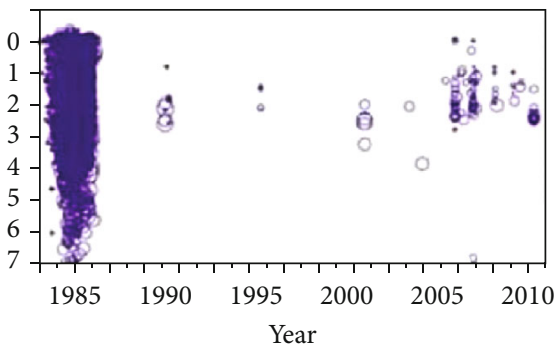

(c)

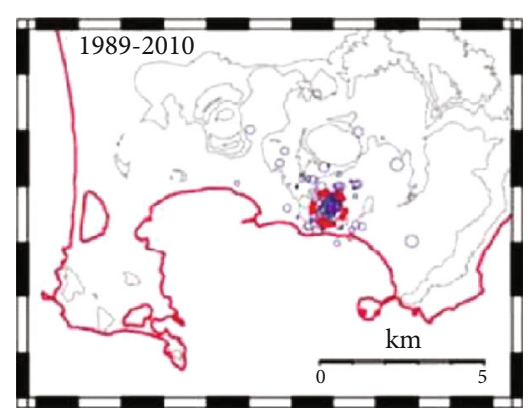

(b)

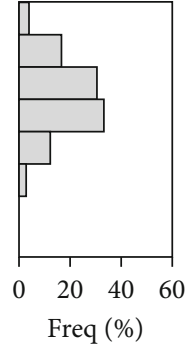

(d)

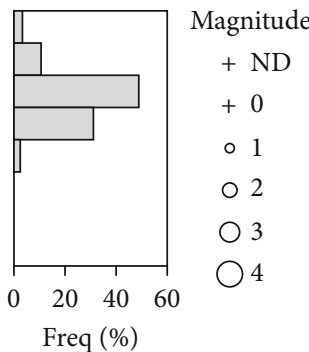

(e)

Figure 3: (a) Blue circles indicate epicenters of earthquakes recorded between 1983 and 1984; the dashed red ellipses mark the two main clusters. (b) The same for the period 1989-2010, the dashed red circle marks the cluster. (c) Hypocenter depths as a function of time. (d) Percentage of hypocenters for each depth range for the period 1982-1984 (the depth scale is the same as for (c)). (e) The same for the period 1989-2010 (from D’Auria et al. [6]).

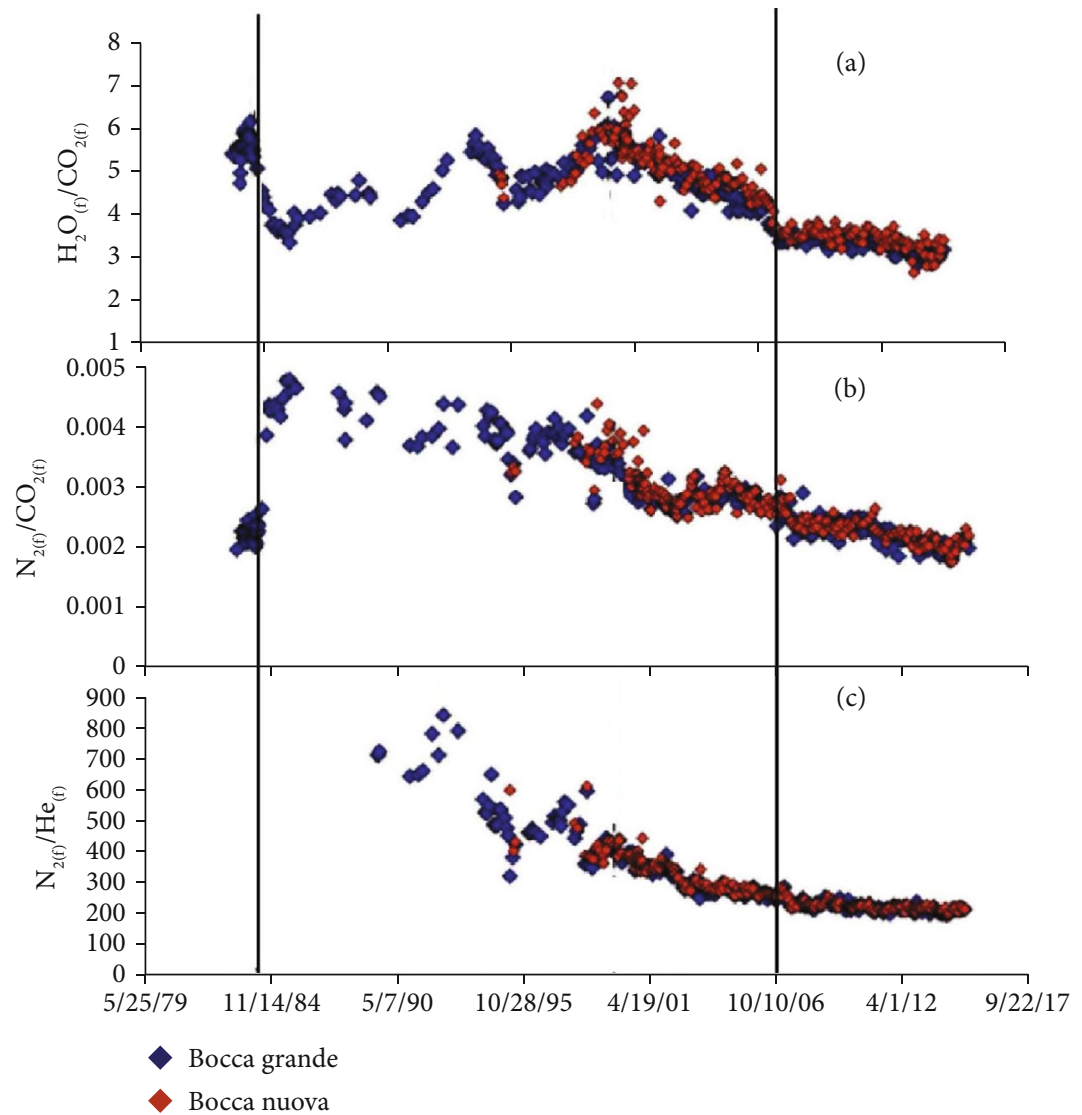

FIgure 4: Gas ratios measured at Solfatara Bocca Grande and Bocca Nuova fumaroles: (a) $\mathrm{H}_{2} \mathrm{O} / \mathrm{CO}_{2}$, (b) $\mathrm{N}_{2} / \mathrm{CO}_{2}$, and (c) $\mathrm{N}_{2} / \mathrm{He}$ (modified from Troise et al. [33]). 

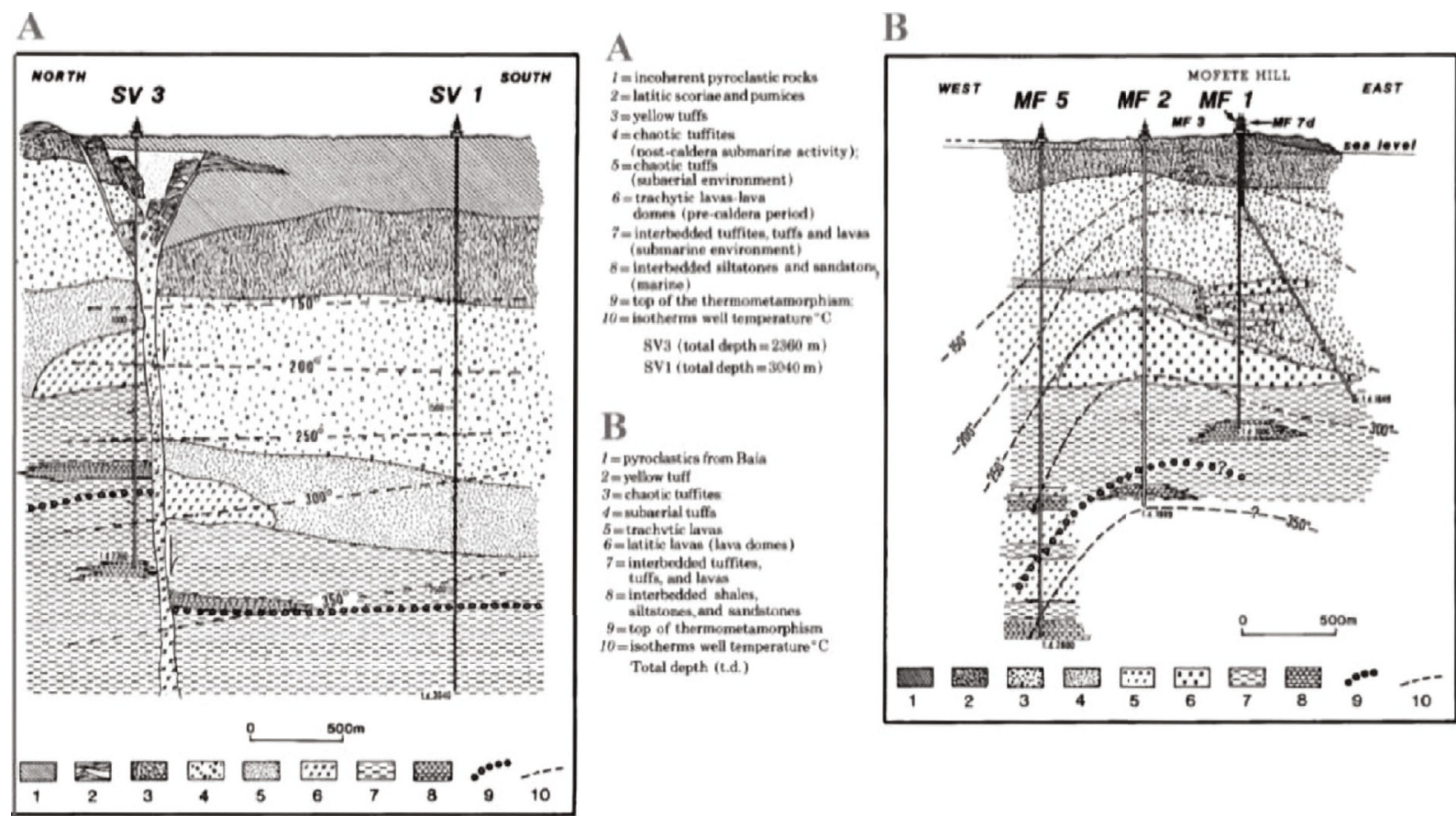

FIGURE 5: (a) Cross-section including SV1 and SV3 wells. (b) Cross-section including MF1, MF2, and MF5 vertical wells. MF3 and MF7d wells are also shown. See Figure 1 for location (from Agip [70]; De Vivo et al. [74]).

A very recent model by Nespoli et al. [67] differs from others mainly in that a magmatic intrusion is not required to explain bradyseism. These workers apply a physical model which considers that a Thermo-Poro-Elastic (TPE) inclusion, with an assigned geometry, is responsible for deformation induced by mechanical effects of both pore pressure and temperature changes of the fluids which pervade a poroelastic region, embedded in an elastic matrix. To explain the CF bradyseism phase during the 1982-1984 period, Nespoli et al. [67] recognized the presence of a layer with timedependent permeability below the shallow aquifer, based on tomography studies performed by Calò and Tramelli [68]. Uplift occurs when fluids cannot pass through this impermeable layer and continues until the increase of pore pressure triggers fractures, increases the permeability, and allows fluids to escape, leading to subsidence. Calò and Tramelli [68] not only highlighted the existence of a seismic layer, which separates the shallow aquifer from the deeper part of the caldera, but also concluded that this layer plays an important role in bradyseismic events.

\subsection{Stratigraphy, Permeability, and Cooling State. Several} wells drilled in the CF area [69-72] for a geothermal exploration program by State Co AGIP-ENEL Joint Venture, and a recent review ([73] and ref. therein) summarizes the crustal structure at CF, revealing both the local stratigraphy and small-scale variability to a depth of $\sim 3 \mathrm{~km}$. Figure 5 shows the stratigraphic sequence in the $3000 \mathrm{~m}$ deep San Vito and Mofete wells ([68] and unpublished data). The uppermost $2000 \mathrm{~m}$ is composed of recent volcanoclastic products. In the San Vito boreholes (Figure 5(a)), a systematic increase in metamorphic grade with depth is observed below about $2 \mathrm{~km}$. The thermal profile associated with this metamorphic aureole suggests that magma was present at a shallower depth $(4-5 \mathrm{~km})$ in the past compared to today $(\geq 7.5 \mathrm{~km})$. The isotherms (Figures 5(a) and 5(b)) show that measured borehole temperatures are lower than paleotemperature obtained by fluid inclusion studies on core from the San Vito and Mofete wells [68]. The lithological characteristics of the well stratigraphic succession (Figure 5) define a permeability structure with two important characteristics. The first is the anisotropy in permeability resulting from the sedimentary layering, with permeability parallel to bedding exceeding the orthogonal component. The second characteristic is the vertical variation of the mean permeability governed by low-permeability layers [73, 74].

Based on stratigraphic relations, from the surface downward the permeability oscillates from high (coarse clastics and volcanoclastics) to low (transgressive siltstones and claystones) to high (debris flows) to low (marine calcarenites and siltstones) to high (fluvial conglomerates) and finally to low (carbonates, thermometamorphic and plutonic rocks) values. Although the vertical permeability structure has not been measured in situ over the whole section, typical values for similar volcanic, sedimentary, and metamorphic rocks suggest variations in the vertical permeability of five to ten orders of magnitude [75]. In addition, at different depths, isolated aquifers with variable salinity, not related to depth, have been intersected during drilling [69]. Such high salinity is confirmed by fluid inclusion studies of the paleogeothermal system [74]. The latter indicates the poor connectivity between confined aquifers unless compromised by episodes of fracturing in response to transient excursions of fluid pressure. The structure and magnitude of the permeability 
field along with episodic fracturing events that transiently increase the fracture permeability are an important component of our model to explain bradyseism at CF.

A more recent study [76] on the elastic and mechanical properties of well cores from San Vito (SV1 and SV2) and Mofete (MF1, MF2, and MF5) by high-resolution microstructural and mineralogical analyses reports the existence of an impermeable layer, confirming earlier exploratory drilling studies by the joint venture AGIP-ENEL $[69,71,72]$. Vanorio and Kanitpanyacharoen [76] stress that the deep impermeable layer is a caprock capable of confining the overpressured fluid-bearing underlying formation. The caprock is able to accommodate the strain as fluids accumulate and pore fluid pressure increases until a critical threshold is exceeded (see below). Borehole sections indicate that carbonate country rocks continue to greater depths than the deepest wells.

\section{Discussion}

3.1. Evolution of a Steady-State Magmatic-Hydrothermal System during Cooling. The study of well cores showed that the CF volcanic system has been cooling for some unknown period of time that extends to the present time. The pyrometamorphic layer, in the San Vito well, is at $2 \mathrm{~km}$ depth, and the thermal profile associated with this metamorphic halo suggests that in the past magma was at a shallower depth of $\sim 4-5 \mathrm{~km}$, compared to its present-day depth of $>7.5 \mathrm{~km}$ [77]. The cooling and downward migration of isotherms are consistent with the comparison between "fossil" temperatures obtained by fluid inclusions [74] and those obtained by borehole measurements in the geothermal wells of San Vito 3 and Mofete 5. Moreover, Mormone et al. [78] reached the same conclusion by studying two cores, taken at depths of -443 and $-506 \mathrm{~m}$, in a $506 \mathrm{~m}$ drill hole in the Piana di Bagnoli area located $3 \mathrm{~km}$ east of Pozzuoli [26]. Sr isotope ratios, determined on feldspars, and $\delta^{13} \mathrm{C}$ and $\delta^{18} \mathrm{O}$ on carbonate veins in tuff, along with mineralogical assemblages, give an equilibrium temperature of at least $160^{\circ} \mathrm{C}$, much higher than temperatures of $60^{\circ} \mathrm{C}$ and $80^{\circ} \mathrm{C}$ measured today at $443 \mathrm{~m}$ and at the bottom of the well, respectively.

\subsection{A Model for the Cyclicity of Uplift and Subsidence Events.} The results of ground deformation and microgravimetric data models applied at CF $[35,36,41,43,51,52,55,59$, 79] give different densities for the bodies causing the deformation because the crust is treated, for the most part, as an isotropic, homogeneous, and elastic medium. The parameterization of these deformation models, including the choices made for the elastic properties and layer thicknesses, leads to inferred densities that vary considerably. At CF, the presence of structural discontinuities and/or elastic heterogeneity, viscoelasticity, and the anisotropy in permeability [73] can confound any simple inversions to obtain densities. In addition, at $\mathrm{CF}$, there are differences in displacement ratios and between uplift and subsidence phases that clearly show that simple models based on homogeneous and elastic crust are gross simplifications of a complex geological environment.
As described by Lima et al. [14], bradyseism results from the complex interplay of two dominant processes operating on very different timescales. The long $\left(10^{3}-10^{4} \mathrm{yr}\right)$ timescale process is associated with the deep, steadily cooling magmatic system $(>7.5 \mathrm{~km}$ deep) with the concomitant migration downward of the solid-melt boundary of the mush zone of the crystallizing magma body. The short timescale $\left(1-10^{2}\right)$ process is associated with the hydrothermal system beneath an impermeable layer $B$ that episodically undergoes failure by fracture (seismicity), connecting the lower lithostatic reservoir with the upper hydrostatic aquifer. Bodnar et al. [13] present a quantitative conceptual model describing this process, and Becker et al. [80] describe fluid-related processes in this environment. Thus, bradyseism is attributable to the variations of the short timescale system related to the confined aquifer. Figure 6 summarizes bradyseism phases during the transition from magmatic to epithermal conditions in a subvolcanic environment based on the model of Fournier [81]; for more details, see Bodnar et al. [13] and Lima et al. [14]. In 1982, unrest started along with low magnitude seismicity (Figure 6(a)), associated with vesiculation (or second boiling; [82]) of residual magma that generated magmatic fluids that remained geopressured (lithostatic) (isobaric crystallization) or even super-geopressured (isochoric crystallization) until fracture propagation enabled the expulsion of magmatic fluids (Figure 6(a)). Unrest continued throughout 1983 with an increasing uplift rate and intense seismicity, often clustered in swarms [83] (Figures 3(a) and 3(c)), due to the geopressured magmatic fluids breaching the brittle carapace (Figure 6(b), layer A), marking the brittle-plastic transition zone (Figure 6(b), see also Becker et al. [80]). Magmatic and hydrothermal fluids mix but remain in a lithostatic pressure regime because they are confined by the relatively impermeable layer B (unit B, in Lima et al. [14]). At this stage, unrest reached the ground deformation peak (Figure 6(b)). At the end of 1984 (Figure 6(c)) after an uplift of $1.79 \mathrm{~m}$, hydrofracture propagation in layer B enables the mixed magmatic and hydrothermal fluids to escape, causing intense seismicity, clustered in swarms, at more superficial levels (Figure 6(c)) [6]; at this stage, the fluid transitions irreversibly from lithostatic to hydrostatic conditions with the expansion of fluids and boiling. The solubility of aqueous silica decreases significantly along this path, leading to silica precipitation and an episode of permeability loss by fracture sealing. Thermodynamic and transport properties of aqueous geofluids change rapidly and dramatically in regions of pressure-temperaturecomposition space around the critical point of $\mathrm{H}_{2} \mathrm{O}[84,85]$, as seen in geothermal well isotherms at a depth of $\sim 3 \mathrm{~km}$, where the temperature is around $400^{\circ} \mathrm{C}$. At the end of 1984, subsidence started and seismicity decreased. At this stage (Figure 6(c)), chemical-physical variations involve the system at a large scale, and fracture healing closed most of the numerous hydrofractures associated with $\sim 16,000$ earthquakes recorded during the 1982-84 bradyseism event. Since 1984, subsidence slowly continued for about 22 years, likely because layers A and B were not completely sealed, with magmatic gases still being detected in the Solfatara fumaroles even if they gradually decreased over time (Figures 4(b) and 


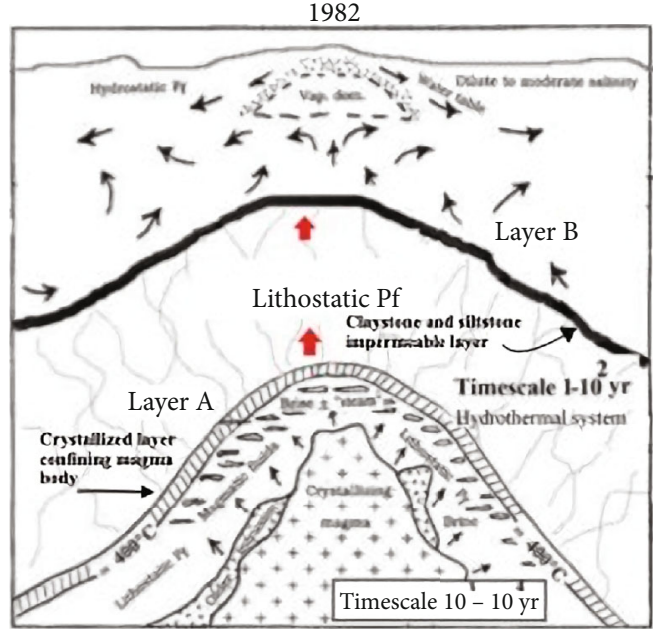

(a)

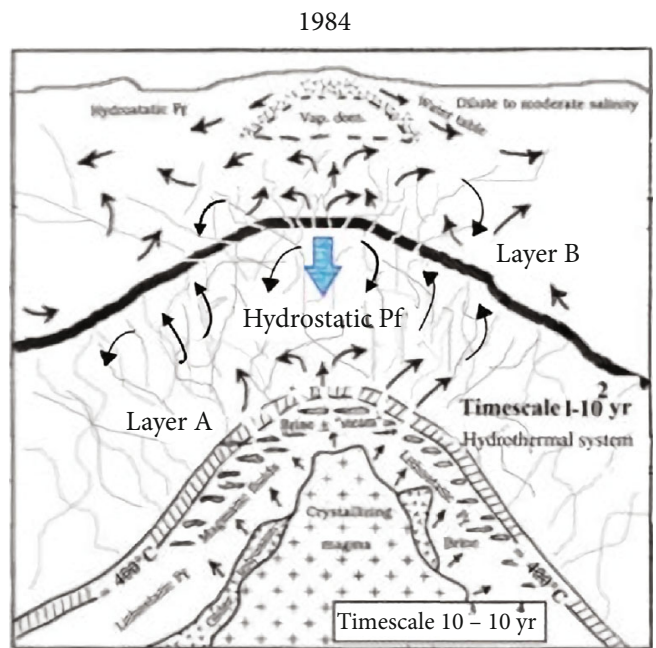

(c)

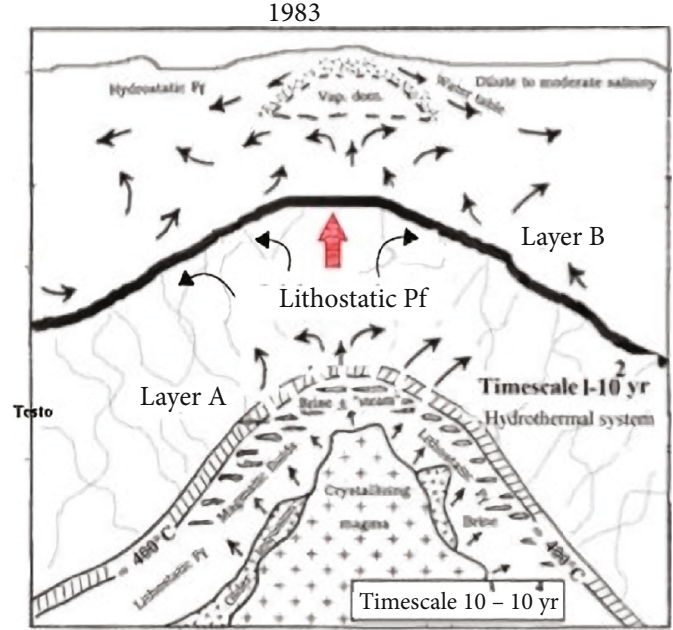

(b)

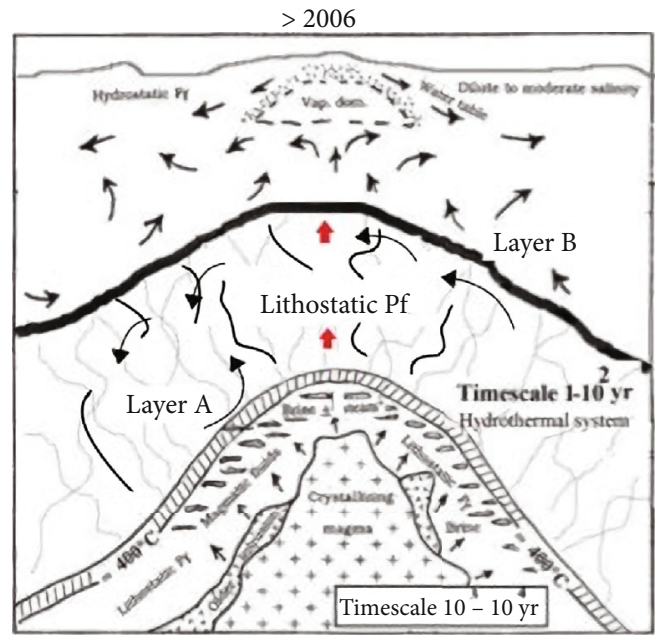

(d)

FIGURE 6: (a) In 1982, uplift started: long timescale magmatic system was sealed by a low permeability carapace (layer A) which blocks hot magmatic fluids that accumulate; short timescale hydrothermal system was closed by low permeability layer (layer B). (b) In 1983, uplift continues: the carapace (layer A) breaks allowing magmatic fluids to enter the overlying confined hydrothermal system. (c) In 1984, impermeable layer B breaks as well triggering subsidence. Pressure regime changes producing faulting, brecciation, hydrothermal alteration, boiling, and silica deposition. Subsidence continues until layer B close by self-sealing. (d) Since 2006 until today, layer B is sealed, and uplift goes on (modified from Fournier [81]).

4(c)). When the system is again completely sealed and the deeper and more shallow aquifers are no longer connected, subsidence stops even if it does not balance uplift completely because the deformation at the macroscopic scale is highly inelastic. Since the end of 2005 (Figure 6(d)), layer B has been sealed, and the vertical deformation recorded at the surface has slowly resumed. Bradyseism is governed by the impermeable layer B, a caprock formed by fibrous minerals and intertwining filaments that confers shear and tensile strength, contributing to its ductility and increased resistance to fracture [76]. The presence of this layer has been highlighted also by tomographic studies of Calò and Tramelli [68]. Following compression/decompression, layer B can act as a mechanical toggle such that connectivity between hydrostatic and lithostatic reservoirs is episodically established. This process is a common mechanism associated with ore deposition in the porphyry systems (see Lima et al. [14], for more details). When connectivity is established and fluid expansion occurs, the temperature increase associated with fluid decompression will lead to a decrease in the solubility of silica in the fluid [86].

Earthquake swarms during bradyseism should be the manifestation of hydrofracturing and crack propagation which act as conduits or paths of egress for aqueous fluid during decompression (volumetric expansion of fluid) [87-89]. In the future, we anticipate that new and evolving methodologies will be applied at CF to better distinguish between different sources of seismicity. As an example, Butcher et al. [90] applied statistical and quantitative approaches to identify a stable source of long-period (LP) seismicity at Cayambe Volcano, Ecuador, that is likely associated with a shallow hydrothermal system. 
Minor episodes of bradyseism have occurred every 5-6 years since 1989 (Figure 2), and associated seismicity, both during uplift and following subsidence, is explained in the context of the short timescale process. At the end of 2005, a new unrest phase started. Compared with 1982, the uplift rate is much slower; in 15 years, the total uplift is $\sim 75 \mathrm{~cm}$, and seismicity is moderate, of low magnitude and with shallow epicenters (Figures 3(a) and 3(c)). It is possible that after 40 years, bradyseism is attenuating, as hypothesized by Lima et al. [14]. However, there is also the possibility that fluids escape from the system through the numerous existing fractures and faults in the CF area (Figure 1(c)) as in the nearby Solfatara-Pisciarelli active areas (Figure 3(b)). In this way, the energy for unrest is reduced and the cooling of the magmatic system is accelerated, pushing the magma-host rock mushy contact zone deeper through time as heat advection by magmatic-hydrothermal migration takes place.

Figure 4 shows the variation in the composition of fumarolic gases recorded at Bocca Grande (BG) and Bocca Nuova (BN) at the nearby Solfatara volcano; both $\mathrm{N}_{2} / \mathrm{CO}_{2}$ (Figure $4(\mathrm{~b})$ ) and $\mathrm{N}_{2} / \mathrm{He}$ (Figure $4(\mathrm{c})$ ) ratios show a decreasing trend since 1984, as it should be if the connectivity between the two systems (magmatic and hydrothermal) is decreasing and considering that $\mathrm{N}_{2}$ and $\mathrm{He}$ are likely hightemperature magmatic gases; after 2006, the decrease is very slow. The current $\mathrm{N}_{2} / \mathrm{CO}_{2}$ ratio is similar to the one measured in 1982 when unrest started. $\mathrm{CO}_{2}$ can have different origins since volcanic, magmatic, and hydrothermal gases are dominated by water and $\mathrm{CO}_{2}$. In addition, at $\mathrm{CF}, \mathrm{CO}_{2}$ can be generated by decarbonation reactions in the wallrocks as well as in the CF basement (see Figure 3 in Lima et al. [14]). The $\mathrm{H}_{2} \mathrm{O} / \mathrm{CO}_{2}$ ratio (Figure $4(\mathrm{a})$ ) decreased rapidly in 1984 when subsidence started. These variations were interpreted [14] to reflect magmatic fluid contribution from the deep magmatic system that follows hydrofracking of both impermeable A and B layers (Figure 6(c)). Afterwards, variations in the $\mathrm{H}_{2} \mathrm{O} / \mathrm{CO}_{2}$ ratio seem to be related to minor unrest events. After 2006, when new unrest started, the $\mathrm{H}_{2} \mathrm{O} / \mathrm{CO}_{2}$ trend decreases more slowly. Increasing $\mathrm{H}_{2} \mathrm{O} / \mathrm{CO}_{2}$ trend is one of the greatest concerns of researchers who interpret it as a signal of a probable eruption (e.g., [57, 60, 63]). Chiodini et al. [66] investigated relationships among hydrothermal temperature-pressure, fluid flow, and earthquakes at CF (always, based on the assumptions that (a) the caldera was formed by CI $39 \mathrm{ka}$ ago-in contrast with the evidences of de Vivo et al. [21], Rolandi et al. [22, 23], and De Natale et al. [26, 27]; (b) bradyseism is caused by magmatic intrusions; and (c) an eruption is imminent) and interpreted the impact of hydrothermal fluid P-T changes on earthquake occurrence and fluid emissions. An increase of the $\mathrm{CO}_{2}$ emission at the surface reflects an increase in the amount of magmatic fluid entering the base of the hydrothermal system, leading to heating and pressurization. The latter contrasts with unrest cyclicity that explains uplift by the episodic opening and closing of a multitude of fractures related to the transient switch between lithostatic and hydrostatic conditions on a short (1-10 yr) timescale.

When considering magmatic and hydrothermal contributions in fumaroles, it is useful to compare the enriched gases in magmas. Both $\mathrm{N}_{2} / \mathrm{CO}_{2}$ (Figure $4(\mathrm{~b})$ ) and $\mathrm{N}_{2} / \mathrm{He}$ (Figure $4(\mathrm{c})$ ) do not show any variations. $\mathrm{H}_{2} \mathrm{O} / \mathrm{CO}_{2}$ ratios of magmatic and hydrothermal gases are within the same range [91]. At Solfatara, deeply derived $\mathrm{CO}_{2}$ commonly occurs in specific areas such as faults, small vents, and steaming ground rather than across the entire volcanic system [91]. Locally at Solfatara-Pisciarelli, changes in $\mathrm{CO}_{2}$ can be caused by activation of fractures (Figure 3(b)), most likely affecting the carbonates, and low seismicity and tremors at shallow depth can be the result of fluid boiling $[88,89]$. On the other hand, in consideration of the complex stratigraphy, permeability, and resistivity [92], a confined aquifer lens locally can also be present. The latter can undergo fluid overpressure for temperature increase, hydraulic fracturing, and closure by silica precipitation in response to phase transition from liquid to vapor at $20 \mathrm{MPa}$ [86]. Likely, this is the case reported for two episodes of seismicity and gas emission that occurred on 7 October 2015 and 6 December 2019 at Solfatara-Pisciarelli area [93], with a sudden increase in the fumarolic tremor amplitude observed during the seismicity episode. The uplift rate decreased immediately after the swarm whereas the fumarolic tremor amplitude remained higher than that observed prior to the swarm. Recently, it has been observed also that shallow volcanic tremors can be related to intense rainfall in the CF area [94].

The model for deformation induced by the ThermoPoro-Elastic (TPE) inclusion reported by Nespoli et al. [67] shows similarities with our model by attributing bradyseism to the presence of a layer with time-dependent permeability capable of episodically preventing the rise of fluids to the surface. In any case, they do not specify a magma role nor if it is in a steady and cooling state and when and why magmatic fluid flow to the surface increases and why bradyseism shows cyclicity over time.

3.3. Bradyseism Signature. At least since the 1970s, when the first vertical leveling was done at CF, the bradyseism ground deformation pattern has remained invariant: a bell shape curve (Figure 7) both during uplift and subsidence episodes with higher rate during uplift, and the maximum uplift centered near Pozzuoli $[7,33,52,95]$.

The constancy of the deformation area along with the constancy of the seismogenic volume during unrest can be considered to represent a "bradyseism signature." The latter involves cyclical events in the same spatial-temporal pattern as discussed above. Magmatic intrusions cannot meet these requirements; they generally follow fractures or paths of less resistance to ascend, it is unlikely each magma pulse would give the same ground deformation pattern again and again, and the magma injection model cannot explain the subsidence following the uplift without very ad hoc and unrealistic assumptions. In addition, the density model built (Figure 8) using a new 3-D inversion of the available highprecision gravity data, and a new digital terrain and marine model [96] characterizing the shallow caldera structure (down to $3 \mathrm{~km}$ depth), highlights a pronounced lowdensity region in the central portion of the caldera, incompatible with the presence of magmatic intrusions. Moreover, 


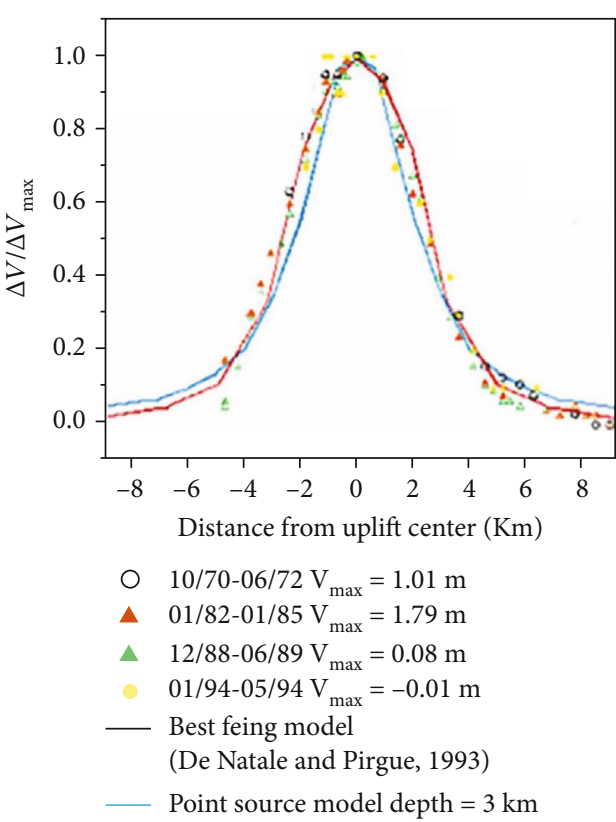

(a)

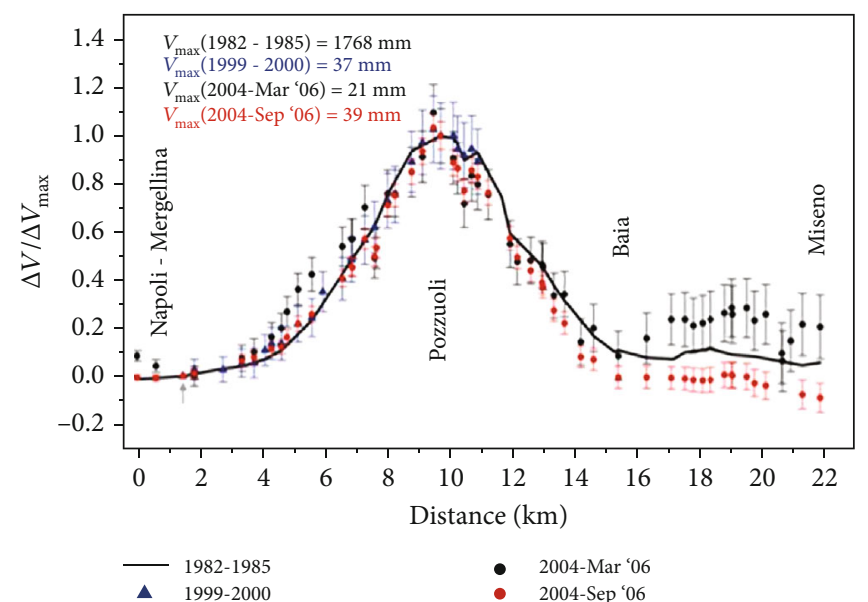

(b)

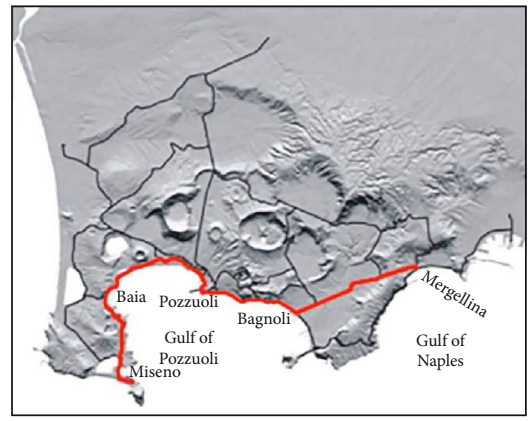

(c)

FIGURE 7: (a) Normalized absolute value of ground displacement data shown as a function of the distance for four different unrest periods (De Natale and Pingue [7]). (b) Normalized absolute value of ground deformation measured by precision levelings (along the red line in (c)) from 1982 to 2006. (c) The main leveling route from Naples to Miseno.

during drilling of 11 geothermal wells (AGIP-ENEL joint venture), which reach a depth of $3.2 \mathrm{~km}$, no magmatic intrusions were found. Trasatti et al. [46] argue that the presence of seismicity to a depth of $4.5 \mathrm{~km}$ and the relatively cold temperatures $\sim 420^{\circ} \mathrm{C}$ encountered during drilling to $\sim 2.7 \mathrm{~km}$ depth at $\mathrm{CF}$ are difficult to reconcile with the presence of magma at $\sim 3 \mathrm{~km}$ depth.

Bradyseism cyclicity requires as a prerequisite a stable geological structure capable of preserving the hydrothermal system without substantial variations for centuries. As illustrated in Figure 1(b), an anticline with a low permeability cap layer is present at a depth of $\sim 3 \mathrm{~km}$. The latter has a pozzolanic composition and a fibril-rich matrix as a result of lime-pozzolanic reactions with formation of fibrous minerals contributing to its ductility and increased resistance to fracture [76]. The caprock restricts the vertical ascent of fluid until a transient and short-lived hydrofracturing episode develops, acting as the bradyseism trigger. The dramatic changes in the thermodynamic properties of $\mathrm{H}_{2} \mathrm{O}$ near the critical point [84] in conjunction with irreversible decompression from a lithostatic to a hydrostatic pressure regime facilitate the deposition of silica and the sealing of fractures in a cyclic manner. The active intracaldera compressional tectonic regime explains both anticline formation and fluid accumulation as illustrated in Figure 6. Earthquakes associated with bradyseism are located close to the town of Pozzuoli and in the middle of the bay near the focus of the tectonic folding (Figure 3(a)). The maximum depth of earthquakes is located at the stratigraphic boundary between the carbonates of the Mesozoic-Cenozoic succession and the overlying stratified clastic succession of Pleistocene age (see Figure 3, in Lima et al. [14]).

Identification of the "bradyseism signature" can be useful in distinguishing events that deviate and could be of greater concern for risk prediction. The 1538 Monte Nuovo eruption did not show the bradyseismic signature, even if it was preceded by about $7 \mathrm{~m}$ of uplift. Ground deformation and the maximum uplift were not centered at Pozzuoli but on the site of the eruption $(\sim 3 \mathrm{~km}$ west of Pozzuoli) $[3,4]$. 


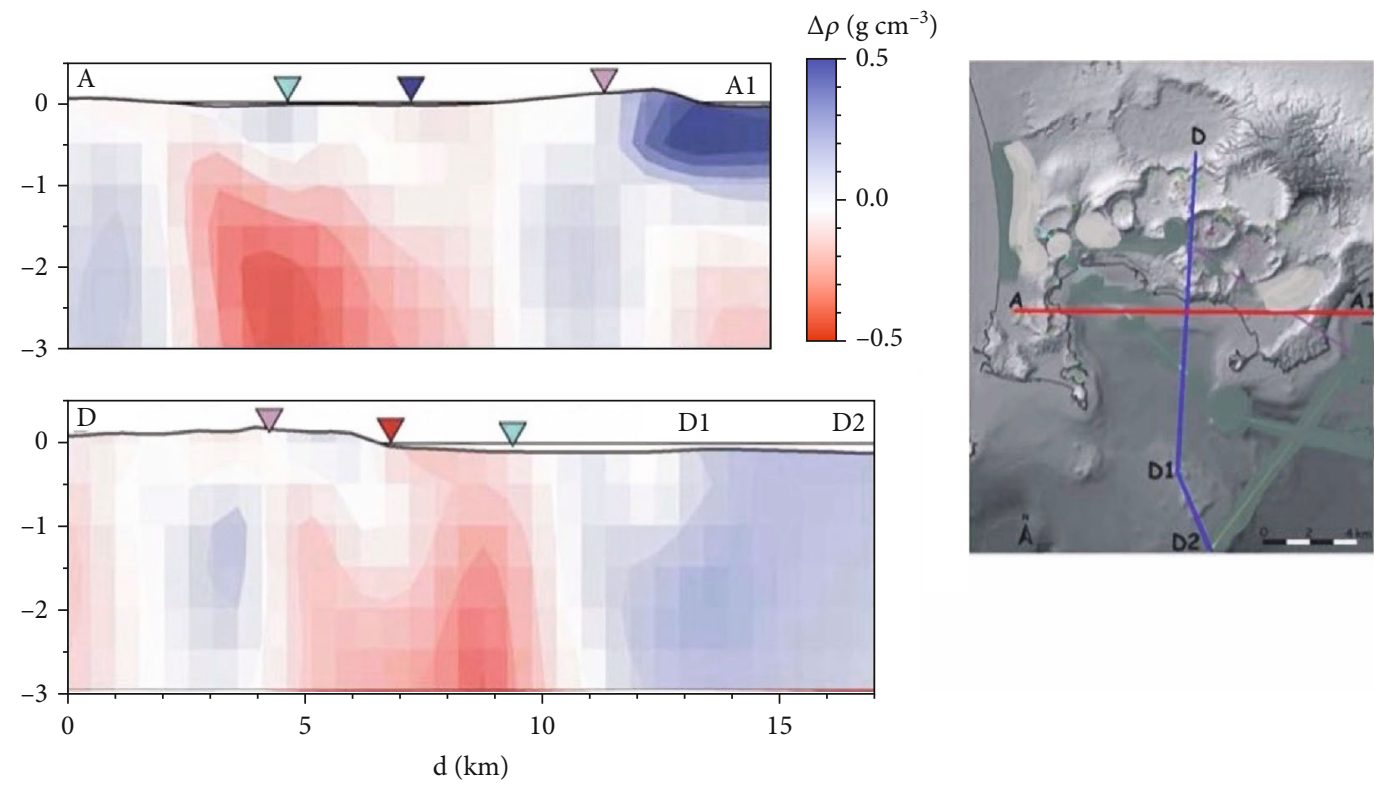

Figure 8: Selected vertical density cross-sections. Locations of the plotted sections are shown in the small map on the right. Color scale represents density contrasts $\left(\mathrm{g} / \mathrm{cm}^{3}\right)$ (modified from Capuano et al. [96]).

3.4. Comparison to Other Caldera Systems. Caldera unrest poses a challenge for eruption forecasting because it may persist for weeks or centuries at large calderas and ground deformation and gravity changes must be correctly interpreted for hazard evaluation. It is critical to differentiate variations of geophysical observables related to volume and pressure changes induced by magma migration from shallow hydrothermal activity associated with hot fluids of magmatic origin rising from depth. To discriminate signals generated by hydrothermal perturbations from those related to magma movement towards the surface is not easy, few ground surface displacement (GSD) models account for significant complexities such as heterogeneities in hydrological and mechanical properties of matrix and geological features like faults, which might influence both the path of ascending magma and the subsurface circulation of hydrothermal fluids. As observed in several large calderas, hydrothermal fluid injection, circulation, and gas formation can generate complex and temporally and spatially varying GSD patterns of deformation rates, magnitudes, and geometries. Cocco et al. [97] proposed a numerical model for evaluating the variations in geophysical parameters associated with the perturbation of the hydrothermal system, using the CF caldera as an example. Throughout simulations of the hydrothermal system dynamics, they observed that heterogeneities in hydrological and mechanical properties as well as the presence of faults within caldera forming volcanoes substantially affect the hydrothermal circulation of hot fluids and the consequent variation in geophysical signals. These results indicate that it is very unlikely that cyclical events in a restless caldera can give rise to the same geophysical signals repeatedly over time as seen for CF "bradyseism signature." Unrest events occurred within several large calderas, including Rabaul, Aira and Iwo-Jima (Japan), Long Valley (California, USA), Yellowstone (Wyoming, USA), Kilauea, and Mauna
Loa (Hawaii, USA) ([98] and ref. therein). In these calderas, we are not aware of invariant ground deformation patterns both during uplift and subsidence episodes with higher rate during uplift, and the maximum uplift centered always in the same restricted area, for many different deformation events. For example, at Yellowstone caldera, geodetic measurements that now include semipermanent Global Positioning System (GPS), continuous GPS, and interferometric synthetic aperture radar (InSAR) have shown the entire caldera floor to be mobile in space and time [99, 100] even if observations of cyclical crustal deformation are key to evaluating the hazards of this active volcanic system and to improve understanding of the relation between time-dependent deformation and magma migration and help to differentiate between hydrothermal and magmatic sources [101].

\section{Conclusions}

A decade ago, the authors proposed a magmatichydrothermal model to explain bradyseism at CF, since over the years the latter has not lost its validity, we reviewed the abundant literature which in the meantime has been published to corroborate our model and to demonstrate that the recent CF bradyseism events are related to cyclical magmatic-hydrothermal processes associated with cooling and crystallization of epizonal, water-bearing magmas. Firstly, we emphasize that bradyseism displays repetitive cyclical signals without substantial variations. At CF, a bell shape ground deformation pattern in which the magnitude of uplift and subsidence decay rapidly with distance from the location of maximum uplift/subsidence defines the "bradyseismic signature" (Figure 7). A constancy is also noted for the seismogenic volume during a bradyseismic episode. The maximum uplift is always centered at Pozzuoli. If 
bradyseism always gives the same signature, it is logical to expect that the generating mechanism is the same and repetitive over time. The models that explain bradyseism due to shallow magmatic intrusions do not support these characteristics that are invariable over time. The results of both seismic tomography $[68,77]$ and the density model built using a new 3-D inversion of the available high-precision gravity data [96] also exclude the presence of magma at shallow levels. "Bradyseismic signature" can be very helpful to distinguish bradyseism from impending eruption precursors. Secondly, by combining the cyclical model with results of other investigations, we show that fresh magma injection is not a prerequisite for bradyseism to occur and that, in the last decades, bradyseism has not been accompanied by shallow magmatic intrusions.

Finally, we highlighted that the cyclic nature of the observed bradyseism is closely related to the complex geological, tectonic, and stratigraphic upper crustal structures that govern spatial and temporal variations of the subsurface permeability. Bradyseism should be governed by the impermeable layer B that is part of an anticlinal geological structure capable of preserving the hydrothermal system without substantial variations for centuries, acting as the throttling valve between the upper aquifer and the deeper hydrothermal short timescale system $\left(1-10^{2} \mathrm{yr}\right)$ under alternatively lithostatic/hydrostatic pressure. Connectivity between hydrostatic and lithostatic reservoirs is episodically turned on and off causing alternatively uplift and subsidence depending on whether permeability by fractures is established or not. Earthquake swarms should be the manifestation of hydrofractures that allow fluid expansion and silica precipitation sealing cracks and isolating again the reservoir. Since 2006, unrest starts again slowly, showing a "bradyseism signature" with an uplift of $\sim 75 \mathrm{~cm}$ in about 15 years, possibly due to the fluids escaping from the system through fractures as evidenced by the increased Solfatara and Pisciarelli fumarole flows (Figures $1(\mathrm{c})$ and $3(\mathrm{~b})$ ). In this way, the energy for unrest is reduced and the cooling of the magmatic system would also be accelerated, pushing the liquidus deeper and deeper. Lima et al. [14] applied rigorous thermodynamic constraints to evaluate ground deformation at $\mathrm{CF}$ and determined that if the system were completely sealed, a maximum uplift of $40 \mathrm{~m}$ for the entire CF would be feasible. In active volcanic environments similar to CF, uplifts of similar magnitudes associated with hydrothermal fluids have been reported previously. As an example, Wicks et al. [100] reported 28 inches $(0.71 \mathrm{~m})$ of uplift over a 5-year period associated with deep hydrothermal fluids at the Yellowstone caldera.

The miniuplift episodes are well explained by the short timescale process. The cyclicity is also highlighted comparing magmatic and hydrothermal contributions in SolfataraPisciarelli fumaroles; both $\mathrm{N}_{2} / \mathrm{CO}_{2}$ (Figure $4(\mathrm{~b})$ ) and $\mathrm{N}_{2} / \mathrm{He}$ (Figure $4(\mathrm{c})$ ) variations and $\mathrm{N}_{2} / \mathrm{CO}_{2}$ ratio in Solfatara fumarolic gases returned to the same values recorded in 1982, when the system was in the same closed condition as today.

According to the model we propose, at present, the probability of an eruption at CF should be the lowest that it has been in the last 500 years and should be expected to decrease further over time because of cooling of the magmatic system. The scenario could change only if new magma arrives from greater depths and supplies the CF deep magma chamber. In this case, the ground deformation pattern should change radically compared with the typical "bradyseism signature."

\section{Conflicts of Interest}

The authors declare that they have no conflicts of interest.

\section{References}

[1] W. Marzocchi, J. Selva, A. Costa, L. Sandri, R. Tonini, and G. Macedonio, "Tephra fall hazard for the Neapolitan area," in Global Volcanic Hazards and Risk, S. Loughlin, S. Sparks, S. Brown, S. Jenkins, and C. Vye-Brown, Eds., pp. 239-248, Cambridge University Press, Cambridge, 2015.

[2] S. Carlino, "Review article: brief history of volcanic risk in Neapolitan area (Campania, Southern Italy): a critical review," Natural Hazards and Earth System Sciences Discussion, 2021.

[3] J. J. Dvorak and G. Mastrolorenzo, "The mechanisms of recent vertical crustal movements in Campi Flegrei caldera, Southern Italy," in The mechanisms of recent vertical crustal movements in Campi Flegrei caldera, southern Italy, vol. 263, 1991.

[4] M. di Vito, L. Lirer, G. Mastrolorenzo, and G. Rolandi, "The 1538 Monte Nuovo eruption (Campi Flegrei, Italy)," Bulletin of Volcanology, vol. 49, no. 4, pp. 608-615, 1987.

[5] G. De Natale, C. Troise, F. Pingue et al., "The Campi Flegrei caldera: unrest mechanisms and hazard," in Mechanisms of Activity and Unrest at Large Calderas, C. Troise, G. Natale, and C. R. J. Kilburn, Eds., vol. 269, pp. 159-171, Geol Soc London Spec Publ, 2006.

[6] L. D'Auria, F. Giudicepietro, I. Aquino et al., "Repeated fluidtransfer episodes as a mechanism for the recent dynamics of Campi Flegrei caldera (1989-2010)," Journal of Geophysical Research, vol. 116, no. B4, article B04313, 2011.

[7] G. de Natale and F. Pingue, "Ground deformations in collapsed caldera structures," Journal of Volcanology and Geothermal Research, vol. 57, no. 1-2, pp. 19-38, 1993.

[8] G. Corrado, I. Guerra, A. Lo Bascio, G. Luongo, and R. Rampoldi, "Inflation and microearthquake activity of Phlegraean Fields, Italy,” Bulletin Volcanologique, vol. 40, no. 3, pp. 169-188, 1976.

[9] F. Barberi, G. Corrado, F. Innocenti, and G. Luongo, "Phlegraean Fields 1982-1984: brief chronicle of a volcano emergency in a densely populated area," Bulletin Volcanologique, vol. 47, no. 2, pp. 175-185, 1984.

[10] F. Barberi, E. Cassano, P. la Torre, and A. Sbrana, "Structural evolution of Campi Flegrei caldera in light of volcanological and geophysical data," Journal of Volcanology and Geothermal Research, vol. 48, no. 1-2, pp. 33-49, 1991.

[11] G. de Natale, A. Zollo, A. Ferraro, and J. Virieux, "Accurate fault mechanism determinations for a 1984 earthquake swarm at Campi Flegrei caldera (Italy) during an unrest episode: Implications for volcanological research," Journal of Geophysical Research, vol. 100, no. B12, pp. 24167-24185, 1995.

[12] B. De Vivo and A. Lima, "A hydrothermal model for ground movements (bradyseism) at Campi Flegrei, Italy," in 
Volcanism in the Campania Plain: Vesuvius, Campi Flegrei, Ignimbrites, B. Vivo, Ed., vol. 9, pp. 289-317, Elsevier, Developments in Volcanology, 2006.

[13] R. J. Bodnar, C. Cannatelli, B. de Vivo, A. Lima, H. E. Belkin, and A. Milia, "Quantitative model for magma degassing and ground deformation (bradyseism) at Campi Flegrei, Italy: implications for future eruptions," Geology, vol. 35, no. 9, pp. 791-794, 2007.

[14] A. Lima, B. de Vivo, F. J. Spera et al., "Thermodynamic model for uplift and deflation episodes (bradyseism) associated with magmatic-hydrothermal activity at the Campi Flegrei (Italy)," Earth-Science Reviews, vol. 97, no. 1-4, pp. 44-58, 2009.

[15] A. Milia, M. M. Torrente, and F. Giordano, "Active deformation and volcanism offshore Campi Flegrei, Italy: new data from high-resolution seismic reflection profiles," Marine Geology, vol. 171, no. 1-4, pp. 61-73, 2000.

[16] A. Milia and M. M. Torrente, "Tectonics and stratigraphic architecture of a peri-Tyrrhenian half-graben (Bay of Naples, Italy)," Tectonophysics, vol. 315, no. 1-4, pp. 301-318, 1999.

[17] A. Milia and M. M. Torrente, "Fold uplift and synkinematic stratal architectures in a region of active transtensional tectonics and volcanism, Eastern Tyrrhenian Sea," Geological Society of America Bulletin, vol. 112, no. 10, pp. 1531-1542, 2000.

[18] A. Milia and M. M. Torrente, "Late-Quaternary volcanism and transtensional tectonics in the Bay of Naples, Campanian continental margin, Italy," Mineralogy and Petrology, vol. 79, no. 1-2, pp. 49-65, 2003.

[19] A. Milia, "The stratigraphic signature of volcanism off Campi Flegrei (Bay of Naples, Italy)," in Stratigraphy and Geology of Volcanic Areas, G. Groppelli and L. Viereck-Goette, Eds., vol. 464 of Special Paper, , pp. 155-170, Geological Society of America, 2010.

[20] S. Carlino and R. Somma, "Eruptive versus non-eruptive behaviour of large calderas: the example of Campi Flegrei caldera (southern Italy)," Bulletin of Volcanology, vol. 72, no. 7, pp. 871-886, 2010.

[21] B. de Vivo, G. Rolandi, P. B. Gans et al., "New constraints on the pyroclastic eruptive history of the Campanian volcanic plain (Italy)," Mineralogy and Petrology, vol. 73, no. 1-3, pp. 47-65, 2001.

[22] G. Rolandi, F. Bellucci, M. T. Heitzler, H. E. Belkin, and B. De Vivo, "Tectonic controls on the genesis of the ignimbrites from the Campanian volcanic zone, southern Italy," in Ignimbrites of the Campanian Plain Spec Issue, B. Vivo and R. Scandone, Eds., vol. 79, pp. 3-31, Mineralogy and Petrology, 2003.

[23] G. Rolandi, G. De Natale, C. R. J. Kilburn et al., "The 39 ka Campanian Ignimbrite eruption: new data on source area in the Campanian Plain," in Vesuvius, Campi Flegrei, and Campanian volcanism, Chapt. 8, B. Vivo, H. E. Belkin, and G. Rolandi, Eds., pp. 175-205, Elsevier, 2020.

[24] G. Orsi, S. de Vita, and M. di Vito, "The restless, resurgent Campi Flegrei nested caldera (Italy): constraints on its evolution and configuration," Journal of Volcanology and Geothermal Research, vol. 74, no. 3-4, pp. 179-214, 1996.

[25] A. Perrotta, C. Scarpati, G. Luongo, and V. Morra, "The Campi Flegrei caldera boundary in the city of Naples," in Volcanism in the Campania Plain: Vesuvius. Campi Flegrei and Ignimbrites, B. Vivo, Ed., pp. 85-96, Elsevier, Amsterdam, 2006.
[26] G. De Natale, C. Troise, M. Piochi et al., The CFDDP 506 M Drilling Activity at Campi Flegrei (Italy): Volcanological and Environmental Clues on the Eastern Sector of the Caldera from Analyses of Mud Log and Cores, 1st International Workshop on Volcano Geology, Madeira, Portugal, 2014.

[27] G. de Natale, C. Troise, D. Mark et al., "The Campi Flegrei Deep Drilling Project (CFDDP): new insight on caldera structure, evolution and hazard implications for the Naples area (Southern Italy)," Geochemistry, Geophysics, Geosystems, vol. 17, no. 12, pp. 4836-4847, 2016.

[28] M. A. di Vito, R. Isaia, G. Orsi et al., "Volcanism and deformation since 12,000 years at the Campi Flegrei caldera (Italy)," Journal of Volcanology and Geothermal Research, vol. 91, no. 2-4, pp. 221-246, 1999.

[29] R. Isaia, M. A. di Vito, S. de Vita, M. Rosi, and A. Sbrana, "Comment on " ${ }^{40} \mathrm{Ar} /{ }^{39} \mathrm{Ar}$ dating of tuff vents in the Campi Flegrei caldera (southern Italy): toward a new chronostratigraphic reconstruction of the Holocene volcanic activity" by Fedele et al. [Bull Volcanol; 73:1323-1336]," Bulletin of Volcanology, vol. 74, no. 1, pp. 293-296, 2011.

[30] C. Scarpati, A. Perrotta, S. Lepore, and A. Calvert, "Eruptive history of Neapolitan volcanoes: constraints from ${ }^{40} \mathrm{Ar} /{ }^{39} \mathrm{Ar}$ dating," Geological Magazine, vol. 150, no. 3, pp. 412-425, 2013.

[31] P. Armienti, F. Barberi, H. Bizojard et al., "The Phlegraean Fields: magma evolution within a shallow chamber," Journal of Volcanology and Geothermal Research, vol. 17, no. 1-4, pp. 289-311, 1983.

[32] C. del Gaudio, I. Aquino, G. P. Ricciardi, C. Ricco, and R. Scandone, "Unrest episodes at Campi Flegrei: a reconstruction of vertical ground movements during 1905-2009," Journal of Volcanology and Geothermal Research, vol. 195, no. 1, pp. 48-56, 2010.

[33] C. Troise, G. de Natale, R. Schiavone, R. Somma, and R. Moretti, "The Campi Flegrei caldera unrest: discriminating magma intrusions from hydrothermal effects and implications for possible evolution," Earth-Science Reviews, vol. 188, pp. 108-122, 2019.

[34] D. Charlton, C. Kilburn, and S. Edwards, "Volcanic unrest scenarios and impact assessment at Campi Flegrei caldera, Southern Italy," Journal of Applied Volcanology, vol. 9, no. 1, p. 7, 2020.

[35] G. Chiodini, M. Todesco, S. Caliro, C. del Gaudio, G. Macedonio, and M. Russo, "Magma degassing as a trigger of bradyseismic events: the case of Phlegrean Fields (Italy)," Geophysical Research Letters, vol. 30, no. 8, p. 1434, 2003.

[36] Y. Fialko, Y. Khazan, and M. Simons, "Deformation due to a pressurized horizontal circular crack in an elastic half-space, with applications to volcano geodesy," Geophysical Journal International, vol. 146, no. 1, pp. 181-190, 2001.

[37] A. Mangiacapra, R. Moretti, M. Rutherford, L. Civetta, G. Orsi, and P. Papale, "The deep magmatic system of the Campi Flegrei caldera (Italy)," Geophysical Research Letters, vol. 35, no. 21, article L21304, 2008.

[38] A. Amoruso, L. Crescentini, and G. Berrino, "Simultaneous inversion of deformation and gravity changes in a horizontally layered half-space: evidences for magma intrusion during the 1982-1984 unrest at Campi Flegrei caldera (Italy)," Earth and Planetary Science Letters, vol. 272, no. 1-2, pp. 181-188, 2008.

[39] I. Arienzo, R. Moretti, L. Civetta, G. Orsi, and P. Papale, “The feeding system of Agnano-Monte Spina eruption (Campi 
Flegrei, Italy): dragging the past into present activity and future scenarios," Chemical Geology, vol. 270, no. 1-4, pp. 135-147, 2010.

[40] L. De Siena, E. Del Pezzo, and F. Bianco, "Seismic attenuation imaging of Campi Flegrei: evidence of gas reservoirs, hydrothermal basins, and feeding systems," Journal of Volcanology and Geothermal Research, vol. 115, article B09312, 2010.

[41] J. Y. L. Woo and C. R. J. Kilburn, "Intrusion and deformation at Campi Flegrei, southern Italy: sills, dikes, and regional extension," Journal of Geophysical Research, vol. 115, no. B12, article B12210, 2010.

[42] A. Mormone, A. Tramelli, M. A. Di Vito, and M. Piochi, "Hydrothermal alteration minerals in buried rocks at the Campi Flegrei caldera, Italia: a possible tool to understand the rock-physics and to assess the state of the volcanic system," Period Mineral, vol. 80, pp. 385-406, 2011.

[43] A. Amoruso and L. Crescentini, "Modelling deformation due to a pressurized ellipsoidal cavity, with reference to the Campi Flegrei caldera, Italy," Geophysical Research Letters, vol. 38, no. 1, 2011.

[44] A. Aiuppa, G. Tamburello, R. di Napoli et al., "First observations of the fumarolic gas output from a restless caldera: implications for the current period of unrest (2005-2013) at Campi Flegrei," Geochemistry, Geophysics, Geosystems, vol. 14, no. 10, pp. 4153-4169, 2013.

[45] R. Moretti, I. Arienzo, L. Civetta, G. Orsi, and P. Papale, "Multiple magma degassing sources at an explosive volcano," Earth and Planetary Science Letters, vol. 367, pp. 95-104, 2013.

[46] E. Trasatti, M. Bonafede, C. Ferrari, C. Giunchi, and G. Berrino, "On deformation sources in volcanic areas: modeling the Campi Flegrei (Italy) 1982-84 unrest," Earth and Planetary Science Letters, vol. 306, no. 3-4, pp. 175-185, 2011.

[47] V. C. Smith, R. Isaia, N. J. Pearce et al., "On deformation sources in volcanic areas: modeling the Campi Flegrei (Italy) 1982-84 unrest," Earth and Planetary Science Letters, vol. 306, no. 3-4, pp. 175-185, 2011.

[48] F. Giudicepietro, G. Macedonio, and M. Martini, "A physical model of sill expansion to explain the dynamics of unrest at calderas with application to Campi Flegrei," Frontiers in Earth Science, vol. 5, 2017.

[49] V. Romano, U. Tammaro, U. Riccardi, and P. Capuano, "Non-isothermal momentum transfer and ground displacements rate at Campi Flegrei caldera (Southern Italy)," Physics of the Earth and Planetary Interiors, vol. 283, pp. 131-139, 2018.

[50] C. Cannatelli, F. J. Spera, R. J. Bodnar, A. Lima, and B. De Vivo, "Ground movement (bradyseism) in the Campi Flegrei volcanic area: a review," in Vesuvius: Campi Flegrei, and Campanian Volcanism, B. Vivo, H. E. Belkin, and G. Rolandi, Eds., pp. 407-433, Elsevier, 2020.

[51] M. Battaglia, C. Troise, F. Obrizzo, F. Pingue, and G. de Natale, "Evidence for fluid migration as the source of deformation at Campi Flegrei caldera (Italy)," Geophysical Research Letters, vol. 33, no. 1, article L01307, 2006.

[52] J. Gottsmann, A. Folch, and H. Rymer, "Unrest at Campi Flegrei: a contribution to the magmatic versus hydrothermal debate from inverse and finite element modeling," Journal of Geophysical Research, vol. 111, no. B7, p. B07203, 2006.
[53] F. Bellucci, J. Woo, C. R. J. Kilburn, and G. Rolandi, "Ground deformation at Campi Flegrei, Italy: implications for hazard assessment," Geological Society, London, Special Publications, vol. 269, no. 1, pp. 141-157, 2006.

[54] A. Amoruso, L. Crescentini, and I. Sabbetta, "Paired deformation sources of the Campi Flegrei caldera (Italy) required by recent (1980-2010) deformation history," Journal of Geophysical Research - Solid Earth, vol. 119, no. 2, pp. 858-879, 2014.

[55] G. Macedonio, F. Giudicepietro, L. D'Auria, and M. Martini, "Sill intrusion as a source mechanism of unrest at volcanic calderas," Journal of Geophysical Research - Solid Earth, vol. 119, no. 5, pp. 3986-4000, 2014.

[56] V. Acocella, R. di Lorenzo, C. Newhall, and R. Scandone, “An overview of recent (1988 to 2014) caldera unrest: knowledge and perspectives," Reviews of Geophysics, vol. 53, no. 3, pp. 896-955, 2015.

[57] G. Chiodini, J. Vandemeulebrouck, S. Caliro et al., "Evidence of thermal-driven processes triggering the 2005-2014 unrest at Campi Flegrei caldera," Earth and Planetary Science Letters, vol. 414, pp. 58-67, 2015.

[58] G. Chiodini, A. Paonita, A. Aiuppa et al., "Magmas near the critical degassing pressure drive volcanic unrest towards a critical state," Nature Communications, vol. 7, no. 1, 2016.

[59] G. Chiodini, J. Selva, E. del Pezzo et al., "Clues on the origin of post-2000 earthquakes at Campi Flegrei caldera (Italy)," Scientific Reports, vol. 7, no. 1, p. 4472, 2017.

[60] R. Moretti, G. de Natale, and C. Troise, "A geochemical and geophysical reappraisal to the significance of the recent unrest at Campi Flegrei caldera (Southern Italy)," Geochemistry, Geophysics, Geosystems, vol. 18, no. 3, pp. 1244-1269, 2017.

[61] R. Moretti, C. Troise, F. Sarno, and G. de Natale, "Caldera unrest driven by $\mathrm{CO}_{2}$-induced drying of the deep hydrothermal system," Scientific Reports, vol. 8, no. 1, p. 8309, 2018.

[62] F. S. Gaeta, F. Peluso, I. Arienzo et al., "A physical appraisal of a new aspect of bradyseism: the miniuplifts," Journal of Geophysical Research, vol. 108, no. B8, p. 2363, 2003.

[63] L. D’Auria, S. Pepe, R. Castaldo et al., "Magma injection beneath the urban area of Naples: a new mechanism for the 2012-2013 volcanic unrest at Campi Flegrei caldera," Scientific Reports, vol. 5, no. 1, p. 13100, 2015.

[64] S. Carlino, C. R. J. Kilburn, A. Tramelli, C. Troise, R. Somma, and G. de Natale, "Tectonic stress and renewed uplift at Campi Flegrei caldera, southern Italy: new insights from caldera drilling," Earth and Planetary Science Letters, vol. 420, pp. 23-29, 2015.

[65] V. di Renzo, K. Wohletz, L. Civetta, R. Moretti, G. Orsi, and P. Gasparini, "The thermal regime of the Campi Flegrei magmatic system reconstructed through $3 \mathrm{D}$ numerical simulations," Journal of Volcanology and Geothermal Research, vol. 328, pp. 210-221, 2016.

[66] G. Chiodini, S. Caliro, R. Avino et al., "Hydrothermal pressure-temperature control on $\mathrm{CO}_{2}$ emissions and seismicity at Campi Flegrei (Italy)," Journal of Volcanology and Geothermal Research, vol. 414, p. 107245, 2021.

[67] M. Nespoli, M. E. Belardinelli, and M. Bonafede, "Stress and deformation induced in layered media by cylindrical thermo-poro- elastic sources: an application to Campi Flegrei (Italy)," Journal of Volcanology and Geothermal Research, vol. 415, p. 107269, 2021. 
[68] M. Calò and A. Tramelli, "Anatomy of the Campi Flegrei caldera using enhanced seismic tomography models," Scientific Reports, vol. 8, no. 1, p. 16254, 2018.

[69] R. Carella and M. Guglieminetti, Multiple Reservoirs in the Mofete Field, Naples, Italy $9^{\text {th }}$ Workshop on Geothermal Reservoir Engineering, Stanford, 1983.

[70] Agip, Geologia e geofisica del sistema geotermico dei Campi Flegrei, internal report, Milan, Italy, 1987.

[71] M. Guglielminetti and G. Tore, "Pit tests in the wells Mofete 1 and 2," in European Geothermal Update, A. S. Strub and P. Ungemach, Eds., pp. 473-483, Third Int. Seminar, 1985.

[72] M. Guglielminetti, "Mofete geothermal field," Geothermics, vol. 15, no. 5-6, pp. 781-790, 1986.

[73] M. Piochi, C. R. J. Kilburn, M. A. di Vito et al., "The volcanic and geothermally active Campi Flegrei caldera: an integrated multidisciplinary image of its buried structure," International Journal of Earth Sciences, vol. 103, no. 2, pp. 401-421, 2014.

[74] B. de Vivo, H. E. Belkin, M. Barbieri et al., "The Campi Flegrei (Italy) geothermal system: a fluid inclusion study of the Mofete and san Vito fields," Journal of Volcanology and Geothermal Research, vol. 36, no. 4, pp. 303-326, 1989.

[75] T. Gleeson, L. Smith, N. Moosdorf et al., "Mapping permeability over the surface of the Earth," Geophysical Research Letters, vol. 38, no. 2, pp. 1-6, 2011.

[76] T. Vanorio and W. Kanitpanyacharoen, "Rock physics of fibrous rocks akin to Roman concrete explains uplifts at Campi Flegrei caldera," Science, vol. 349, no. 6248, pp. 617621, 2015.

[77] A. Zollo, N. Maercklin, M. Vassallo, D. Dello Iacono, J. Virieux, and P. Gasparini, "Seismic reflections reveal a massive melt layer under Campi Flegrei volcanic field," Geophysical Research Letters, vol. 35, article L12306, 2008.

[78] A. Mormone, C. Troise, M. Piochi, G. Balassone, M. Joachimski, and G. de Natale, "Mineralogical, geochemical and isotopic features of tuffs from the CFDDP drill hole: hydrothermal activity in the eastern side of the Campi Flegrei volcano (southern Italy)," Journal of Volcanology and Geothermal Research, vol. 290, pp. 39-52, 2015.

[79] G. Berrino, G. Corrado, and U. Riccardi, "Sea gravity data in the Gulf of Naples. A contribution to delineating the structural pattern of the Phlegraean Volcanic District," Journal of Volcanology and Geothermal Research, vol. 175, no. 3, pp. 241-252, 2008.

[80] S. P. Becker, R. J. Bodnar, and T. J. Reynolds, “Temporal and spatial variations in characteristics of fluid inclusions in epizonal magmatic-hydrothermal systems: applications in exploration for porphyry copper deposits," Journal of Geochemical Exploration, vol. 204, pp. 240-255, 2019.

[81] R. O. Fournier, "Hydrothermal processes related to movement of fluid from plastic into brittle rock in the magmaticepithermal environment," Economic Geology, vol. 94, no. 8, pp. 1193-1211, 1999.

[82] C. W. Burnham, "Magmas and hydrothermal fluids," in Geochemistry of Hydrothermal Ore Deposits, H. L. Barnes, Ed., pp. 71-136, Wiley, New York, 1979.

[83] G. De Natale and A. Zollo, "Statistical analysis and clustering features of the Phlegrean Fields earthquake sequence (May 1983- May 1984)," Bulletin of the Seismological Society of America, vol. 76, pp. 801-814, 1986.
[84] R. J. Bodnar and J. K. Costain, "Effect of varying fluid composition on mass and energy transport in the earth's crust," Geophysical Research Letters, vol. 18, no. 5, pp. 983-986, 1991.

[85] J. S. Cline and R. J. Bodnar, "Direct evolution of brine from a crystallizing silicic melt at the Questa, New Mexico, molybdenum deposit," Economic Geology, vol. 89, no. 8, pp. 17801802, 1994.

[86] A. Okamoto, R. Yamada, H. Saishu, and N. Tsuchiya, "Porosity and permeability evolution induced by precipitation of silica under hydrothermal conditions," Procedia Earth and Planetary Science, vol. 17, pp. 249-252, 2017.

[87] S. A. Wood and F. J. Spera, "Adiabatic decompression of aqueous solutions: applications to hydrothermal fluid migration in the crust," Geology, vol. 12, no. 12, pp. 707-710, 1984.

[88] R. C. Leet and S. D. Malone, "Boiling in hydrothermal systems may cause volcanic tremor. AGU 1990 fall meeting," EOS, Transactions, vol. 71, no. 43, p. 1675, 1990.

[89] R. C. Leet, "Investigation of hydrothermal boiling and steam quenching as possible sources of volcanic tremor and geothermal ground noise," $\mathrm{PhD}$ thesis. University of Washington, Seattle, WA, 1991.

[90] S. Butcher, A. F. Bell, S. Hernandez, and M. Ruiz, "Evolution of seismicity during a stalled episode of reawakening at Cayambe Volcano, Ecuador," Frontiers in Earth Science, vol. 9, p. 680865, 2021.

[91] T. P. Fisher and G. Chiodini, "Volcanic, magmatic and hydrothermal gases," in The Encyclopedia of Volcanoes Edition, Chapter 45, H. Sigurdsson, B. Houghton, S. McNutt, H. Rymer, and J. Stix, Eds., pp. 779-797, Elsevier, 2015.

[92] A. Siniscalchi, S. Tripaldi, G. Romano et al., "Reservoir structure and hydraulic properties of the Campi Flegrei geothermal system inferred by audiomagnetotelluric, geochemical, and seismicity study," Journal of Geophysical Research, vol. 124, no. 6, pp. 5336-5356, 2019.

[93] F. Giudicepietro, G. Chiodini, R. Avino et al., "Tracking episodes of seismicity and gas transport in Campi Flegrei caldera through seismic, geophysical, and geochemical measurements," Seismological Research Letters, vol. 92, no. 2A, pp. 965-975, 2020.

[94] N. Scafetta and A. Mazzarella, "On the rainfall triggering of Phlegraean Fields volcanic tremors," Watermark, vol. 13, no. 2, p. 154, 2021.

[95] G. de Natale, S. Petrazzuoli, and F. Pingue, "The effect of collapse structures on ground deformations in calderas," Geophysical Research Letters, vol. 24, no. 13, pp. 15551558, 1997.

[96] P. Capuano, G. Russo, L. Civetta, G. Orsi, M. D'Antonio, and R. Moretti, "The active portion of the Campi Flegrei caldera structure imaged by 3-D inversion of gravity data," Geochemistry, Geophysics, Geosystems, vol. 14, no. 10, pp. 4681-4697, 2013.

[97] A. Coco, J. Gottsmann, F. Whitaker et al., "Numerical models for ground deformation and gravity changes during volcanic unrest: simulating the hydrothermal system dynamics of a restless caldera," Solid Earth Discussions, vol. 7, no. 2, pp. 557-577, 2016.

[98] C. G. Newhall, F. Costa, A. Ratdomopurbo et al., "WOVOdat - an online, growing library of worldwide volcanic unrest," Journal of Volcanology and Geothermal Research, vol. 345, pp. 184-199, 2017. 
[99] D. Dzurisin, C. W. Wicks, and M. P. Poland, History of Surface Displacements at the Yellowstone Caldera, Wyoming, from Leveling Surveys and InSAR Observations, 1923-2008, U. S. Geological Survey Professional Paper 1788, 2012, https://pubs.usgs.gov/pp/1788/.

[100] C. W. Wicks, D. Dzurisin, J. B. Lowenstern, and J. Svarc, "Magma intrusion and volatile ascent beneath Norris Geyser Basin, Yellowstone National Park," Journal of Geophysical Research - Solid Earth, vol. 125, no. 2, article e2019JB018208, 2020.

[101] W. L. Chang, R. B. Smith, J. Farrell, and C. M. Puskas, "An extraordinary episode of Yellowstone caldera uplift, 20042010, from GPS and InSAR observations," Geophysical Research Letters, vol. 37, no. 23, article L23302, 2010. 